TADEUSZ LEWASZKIEWICZ

Uniwersytet im. Adama Mickiewicza w Poznaniu

ORCID: 0000-0003-0676-9841

e-mail: lewtad@interia.pl

\title{
ZAINTERESOWANIA JĘZYKOZNAWCZE ZYGMUNTA KRASIŃSKIEGO
}

\section{Uwagi wstępne}

W historii wielu języków świata pisarze, thumacze i publicyści zajmowali się językoznawstwem, a niektórzy byli nawet kodyfikatorami i reformatorami języków (Lewaszkiewicz 2017). Gdy chodzi o świat słowiański, odegrali oni szczególną rolę w historii następujących języków: czeski (Josef Jungmann), słowacki (L'udovit Štúr), serbski (Vuk Stefanović Karadżić), macedoński (Błaże Koneski), rosyjski (Michaił Łomonosov). Zwykle jednak pisarze wypowiadali się o różnych aspektach języka w taki sposób, że nie można tych rozważań rozpatrywać w kategoriach dociekań naukowych. Są to po prostu zainteresowania językoznawcze i wypowiedzi informujące o charakterze świadomości językowej pisarzy. Zasługują one jednak na opracowania naukowe.

W Polsce przynajmniej kilkudziesięciu pisarzy zainteresowało się teoretycznymi problemami języka polskiego, ale nikt $\mathrm{z}$ tego grona nie wzbogacił dorobku językoznawstwa polskiego oraz nie przyczynił się do reformowania i kodyfikacji polszczyzny. $\mathrm{W}$ miarę pełną listę tych pisarzy wraz $\mathrm{z}$ omówieniem i oceną ich uwag ,językoznawczych" zamieszczę w osobnym opracowaniu. W tym miejscu wymienię tylko wybrane nazwiska i podam ważniejsze pozycje bibliograficzne: Adam Mickiewicz (Walczak 1998, 1999, 2010), Cyprian K. Norwid (Lewaszkiewicz, Walczak, Zgółkowa 1984), Józef I. Kraszewski (Pihan 1990), Stefan Żeromski (Papierkowski 1972), Melchior Wańkowicz (Sokólska 2015).

Zygmunt Krasiński (1812-1859) to niezwykła postać w historii literatury polskiej. Był poetą, powieściopisarzem i przede wszystkim dramaturgiem. W jego filozofii dominowało przekonanie o decydującym wpływie Boga na historię. Jest przede wszystkim znany jako autor dwóch dramatów: Nie-Boskiej komedii (1835) i Irydiona (1836). 
Przyszły pisarz pobierał najpierw nauki w domu. W 1827 roku ukończył Liceum Warszawskie, następnie przez dwa lata studiował prawo na Uniwersytecie Warszawskim. We wczesnej młodości poznawał romantyczną literaturę zachodnioeuropejską głównie na podstawie źródeł francuskich (Janion 1962); w języku francuskim uprawiał wówczas prozę poetycką.

Bardzo dobra znajomość francuskiego wpływała niewątpliwie korzystnie na jego polską świadomość językową. W czasach szkolnych uczył się z pewnością łaciny (prawdopodobnie też podstaw greki). Podczas pobytu w Niemczech pogłębił znajomość niemieckiego, chyba radził sobie z lekturami w języku angielskim. W jego listach pojawiały się liczne cytaty z francuskiego, niemieckiego i łaciny, co świadczy o obyciu z tymi językami.

Językiem i stylem Krasińskiego zajmowano się już wielokrotnie, ale wyniki badań nie są imponujące. Omówiłem te publikacje w osobnym artykule (Lewaszkiewicz w druku). Szczególnie istotnym składnikiem stylu autora Irydiona są jego osobliwości leksykalne, tj. neologizmy pewne i wątpliwe, formacje potencjalne i wyrazy po prostu rzadkie. Prawdopodobnie wszystkie teksty pisarza dokumentują ponad 2500 takich jednostek leksykalnych. Wydaje się, że żaden polski pisarz nie dorównał mu pod tym względem, tj. również pod względem dziwactwa leksykalnego.

Każdy pisarz (zwłaszcza pisarz nieprzeciętny) zastanawia się nad istotą języka jako tworzywa utworów literackich. Dociekania te obejmują zagadnienia ortograficzne, gramatyczne, poprawność i kulturę języka, styl. Ale tylko część pisarzy zajmuje się fachowymi zagadnieniami językoznawczymi w odrębnych publikacjach lub pozostawia ślady swoich przemyśleń w publicystyce, w korespondencji lub osobistych notatkach. Takie uwagi językoznawcze znajdują się w listach Krasińskiego do Delfiny Potockiej (zob. Edycje listów) oraz w listach do Augusta Cieszkowskiego ${ }^{1}$ (zob. Edycje listów). Stanowią one przedmiot niniejszego artykułu. Omawiam je i oceniam w odpowiednich grupach tematycznych. Jest ich niewiele w porównaniu z wypowiedziami ,językoznawczymi” innych pisarzy, np. Mickiewicza, Norwida, Żeromskiego. W przyszłości zapewne można będzie udokumentować nowe fakty tego typu, które znajdują się w niewykorzystanej przeze mnie korespondencji (także do Delfiny Potockiej) i w innych tekstach.

Warto zacytować fragment wstępu Jana Kotta do wydania części listów Krasińskiego do Delfiny Potockiej:

Wśród wszystkich listów Krasińskiego listy do Delfiny zajmują miejsce wyjątkowe. Są zbiorem największym i najintensywniejszym. Ilość tych listów, według oceny Żółtowskiego, wynosiła pięć tysięcy półarkusików listowego papieru. Krasiński potrafił pisać do Delfiny codziennie, nieraz rano i wieczór. Ale o niezwykłości tej korespondencji mówią nie tylko jej rozmiary. Układa się ona w zadziwiający romans listowny, który można by nazwać największą powieścią polskiego romantyzmu, tą powieścią, której nie było (L-D: 10).

${ }^{1}$ A. Cieszkowski (1814-1894), filozof, ekonomista i działacz społeczny, był jednym z najważniejszych przyjaciół Krasińskiego. Ich korespondencja często dotyczyła skomplikowanej problematyki filozoficznej. 


\section{Uwagi językoznawcze w listach do Delfiny Potockiej}

Przywołując postać Henryka Rzewuskiego (1791-1866), autora gawędy szlacheckiej, znanej pod skróconym tytułem Pamiętnik Soplicy, Krasiński wzmiankował, że zna on „piętnaście języków żyjących, a siedem umarłych” (L-D: 36). Uwaga ta świadczy, że cenił znajomość języków obcych, zwłaszcza wielojęzyczność.

Najważniejszy w ukazaniu zainteresowań językoznawczych Krasińskiego jest jego list do Delfiny Potockiej z 17.01.1842 (L-D: 64-68). Pisarz chciał, aby jego korespondentka doskonaliła się w znajomości języka polskiego. W dalszej części listu zwraca uwagę na błędy ortograficzne i językowe, ale na początku listu w zasadzie ocenia pozytywnie jej polszczyznę i zachęca do pisania w języku ojczystym.

Droga moja! Twój rysunek jeszcze zawczoraj w wieczór doszedł mnie i mało mnie jedna bestia nie pożarła, a druga, ta strzałami naszpikowana, nie przywiodła do nerwowych trzęsień. Czasem śnią się takie formy podczas zmory - później, gdym czytał całą historię Dyszego, małom się nie rozpłakał, ślicznie po polsku napisana, niech Dysz wcale nie myśli, że źle pisze, i nie wstydzi się, owszem, Dysz pisze po polsku jak mało która - nie powiem, który - ale k t ó r a w Polsce. Czasem Dysz się pomyli w pisowni, czasem w składni, ale to wszystko zniknie przez używanie, nic, jedno pisanie pisać naucza, czytać i pisać, język wyssany z mlekiem i tylko w głębi Ducha drzemiący sam się rozbudzi, przyjdzie do siebie, odnajdzie siebie (L-D: 64).

Na uwagę zasługuję wprawdzie nieoryginalne, ale jednak trafne spostrzeżenie, że nieporadność językową można ograniczyć poprzez czytanie i pisanie.

Dalej następują rozważania o pochodzeniu języków, tj. z zakresu glottogonii. Nie mają one charakteru naukowego, lecz zdecydowanie religijny i mistyczny; w dużym stopniu są podobne do przemyśleń przedstawicieli tzw. dziewiętnastowiecznego ,językoznawstwa natchnionego", które reprezentują przede wszystkim Jan N. Kamiński i Feliks Jezierski (Kurkowska 1950). Oto obszerny cytat odzwierciedlający pogląd Krasińskiego na istotę języka:

Język każden objawieniem jest Bożym i bardzo mistycznym. Nie wiemy, ni jak się tworzą, ni jak się wzięły języki. Znakiem, że Duch Święty udzielony został apostołom, była władza mówienia rozmaitymi języki. Zdarzały się przypadki, że osoby w wielkiej gorączce lub zachwycie Ducha, lub w magnetycznym stanie, lub w godzinę skonu podobnież daru tego nagle dostawały. Pani Błażejowa Krasińska, ta, przy której biskup kamieniecki pochować się kazał, konając, nagle do niego po grecku przemówiła, choć nigdy wprzódy nie umiała ni słowa w tym języku, i kazała mu zostać z generała artylerii księdzem, a to dla dzielniejszego ratowania upadającej Rzeczypospolitej. Język jest wprost żywym objawieniem Bożego Ducha na tym świecie.

Przez język sami siebie rozumiemy, pojmujemy, my mieszkamy Duchem w formie żywej mową zwanej - to granica, to świat, to kształt, to drogi mleczne, gwiazdy, słońca, księżyce bez końca, na które eter Ducha naszego się kraje, dzieli, rozgranicza, a jednak zawsze jednym i tym samym zostaje! Język każdy z tysiącami słów jest jak ulotniony wszechświat, jak rytmiczne u n i v e r s u m złożone z dźwięków, a wszystkie ruchy jego są (pewnym tego) podobne do żywych biegów tych wszystkich złotych słów Bożych, krążących po przestrzeni, wiążących się w frazesa zwane konstelacjami, w poemata zwane drogami mlecznymi, w pojedyncze wyrazy zwane planetami, w całkie periody zwane systemami słonecznymi, wreszcie 
w język uniwersalny, ten Boży, zwany wszechnaturą! Ale to u n i v e r s u m niezawodnie prozą nie jest, tak jak ludzki język w samych początkach swych prozą nie był, prozy nie znał, ciągle miarowymi, muzycznymi spadkami buchał z piersi ludzkich. Wszechświata skład i tok rytmicznym być musi. Wszystkie tam słowa metryczne, wszystkie wiersze rymowane $i$ to Bożymi rymy, najrozmaitszymi, jednak zgodnymi! Otóż język jest objawieniem ruchu, składu, miary wszechświata - jest słowem Bożym zewsząd nas! (L-D: 64-65).

Na podstawie tego cytatu trudno o sformułowanie poglądu Krasińskiego na pochodzenie języków ludzkich i ich istotę, ponieważ myśli pisarza są przedstawione w nieracjonalny sposób. Wprost zadziwia irracjonalne przekonanie, że Błażejowa Krasińska w chwili śmierci przemówiła do biskupa kamienieckiego po grecku, chociaż nigdy w życiu nie uczyła się tego języka.

Rozumienie gramatyki też jest pozbawione sensu, nawet w ujęciu filozoficznym: „Gramatyki wszystkie są nudą nud, są tylko trupem języka rozsiekanym - prawdziwy język żywy jest w głębi naszych piersi” (L-D: 65). I w dalszej części listu zachęca Delfinę do używania języka: „Sięgaj więc, Dialy, po język Twój rodzimy w głębi Ciebie samej, wywołuj go stamtąd z upragnieniem, wywoływaj go miłością [...]" (L-D: 65-66). Następne przemyślenia są racjonalne. Autor Nie-Boskiej komedii gani tych, którzy nie pielęgnują języka ojczystego i przyczyniają się do jego utraty: „Kto język swój zatraca, biada temu - własny herb swój maże, odrzuca, hańbi, historii się zapiera, do ludzkości przestaje należeć, bo ten tylko do ludzkości należy, kto jej służy właściwym sobie sposobem, różnym od sposobów, którymi inni jej służą” (L-D: 66). Dalsze stwierdzenie jest słuszne, chociaż nieodkrywcze: „Język przede wszystkim czyni naród taki członkiem żywym ludzkości, [...]” (L-D: 66). Uzasadnienie tej myśli ma jednak charakter „,bełkotu” filozoficznego. Język ojczysty uważa za podstawę tożsamości narodowej („Dopóki plemię jakie mówi mową swoją, dopóty niezwalczone" - L-D: 66), po czym następują dosyć długie wywody religijno-filozoficzne, które nie mają naukowego znaczenia. Ilustracją tego stwierdzenia może być cytat: ,[...] prawdziwie język jest to, co naród jaki r e 1 i g a t ['wiąże' - T. L.] do Ducha do interwencji i do Boga!” (L-D: 67).

Znacznie ciekawsze i lepiej ilustrujące świadomość językową i zainteresowania językoznawcze Krasińskiego są jego uwagi poprawnościowe o języku i pisowni Delfiny Potockiej. Zacytujmy najpierw obszerny fragment listu:

Mam więc nadzieję, żem Dyszę, o ilem mógł, oświecił we względzie grzechu jej dotychczasowego i że raz tak wyłamawszy się spod niego, gdyż nie zaprzestanie na tej drodze coraz wzlatywać wyżej, coraz wysmuklej i śliczniej, i cudniej wyrażać się danym jej przez Boga wyrazem, zmartwychwstawać z grobu obczyzny, skrzydłami własnymi Ducha swojego! „C a $ł$ ą $t$ ę z i m ę wa $1 \mathrm{k}$ ę już mi ałam wielką między 1 e pszym, buntującym się ja a 1 e k k o m y śl ny m D y y s z e m". Zamiast m i a $ł$ a m, w y tr z y m a $ł$ a m albo zniosłam, albo resz tę całą zimę już zachodziła 1 ub toczyła się stras zna walka między etc., etc. „Konsolującym jest”- pocieszającym. „Otoczeni tylu piękności a mi” - tylą albo tylo ma, lecz ładniej t y lą! T y $1 \mathrm{u}$ jest drugi lub siódmy przypadek, np. z t y l u pi ę kn oś c i a 1 b o w ty 1 u p i ęk n o ś c i a c h. Lecz tę myłkę wielu u nas popełnia; ,p o ł o ż e s i ę" - p o ło ż ę s i ę zawsze Ty ę opuszczasz, kiedy mówisz o sobie, piszesz $\mathrm{k} \nmid$ a d e zamiast $\mathrm{k} \nmid \mathrm{a} d$ ę, $\mathrm{p}$ i s z e zamiast p i s z ę-a w ostatnim np. to: p i s z e znaczy trzecią osobę, on p i s z e, kiedy tymczasem Ja nie pi is ze, ale pis z ę! Myśle zamiast myślę! C z u j e zamiast c z uję! 
„W i d z i a 1 a m w c z o r a j R o t t e r. - c h c ę w y j ść n a w i e lk i e g o a r t y s t ę" - tu znowu ponieważ o Rotter. mowa, to nie $\mathrm{c} \mathrm{h}$ c ę, ale c h c e! „O c z y m w ą t p i e" - ponieważ to Ty wątpisz, więc w ą t p i ę zamiast w ą t p i e! Oto są nic nie znaczące błędy ortograficzne, którem wyszperał w Twoim liście, a żadnego, prócz pierwszego, nie ma co do żywej składni języka, a to Duch i grunt! (L-D: 67-68).

Na komentarz zasługują uwagi o końcówce 1. os. 1p. czasu teraźniejszego -ę oraz 3. os. lp. -e. Dotyczą ortografii, ale też częściowo wymowy, ponieważ już w XIX wieku był zaawansowany proces denazalizacji wygłosowego -ę. Delfina Potocka zapisywała 1. os. lp. tak, jak słyszała, tj. jako -e. Pojawienie się -e w 3. os. lp. świadczy o brakach w ortografii i gramatyce.

Przytoczone na początku cytatu nieporadne sformułowania z listu korespondentki Krasiński zastępuje stylistycznie nienagannym zdaniem. Następnie poucza, że zamiast konsolujacym lepiej jest użyć pocieszającym. Zbędna była - moim zdaniem poprawka tyla pięknościami zamiast tylu pięknościami. W połowie XIX w. tylu było prawdopodobnie bardziej potoczne niż tyla. Zwyciężyły formy tylu i tyloma (ta ostatnia dopuszczana także przez Krasińskiego).

Na zagadnienia gramatyczne (dotyczące błędnego używania biernika zamiast dopełniacza) autor Irydiona zwraca uwagę w liście z 26.10.1845 (L-D: 213): „Za wiersze s t o r a z y, bez skazy, dziękuję $\mathrm{Ci}$, Didysz, mocno, po polsku coraz łatwiej Ci idzie, tylko wiecznieś niepoprawna w używaniu czwartego, zamiast drugiego przypadku tam, gdzie zachodzi negacja, np. by nie czuć do tej roztrzepanej istoty wstręt $i$ antypatis (antypatią chciałaś powiedzieć). Otóż trzeba było: wstrętu $i$ antypatii. Uważałem także: dziękuję go, zamiast mu".

Przesłany przez Krasińskiego jego dziecięcy zeszycik z nieudolną ortografią miał zapewne zasugerować Delifinie, że może dojść do wprawy w ortografii, tak jak się to udało nadawcy listu:

W tych dniach przewracając stare, odwieczne papiery, znalazłem ten maleńki kajecik, który pisałem mając lat 6 . Wziąłem go i ślę go Tobie, bo wiem, że Cię roztkliwi serce Siżisa sześcioletnie, bonę swoją kochające i dedykujące jej un conte de Fée ortografia Cię zabawi (L-D: 117).

Niejasna jest przytoczona poniżej wypowiedź pewnej zakonnicy o Andrzeju Towiańskim i jego zwolennikach (nawet na tle całego listu): „Ci ludzie psują język polski. Mistrz, po polsku, to kat” (L-D: 288). Jak się wydaje, Krasiński jest tego samego zdania. Chodzi zapewne nie tylko o krytykę języka (raczej stylu) Towiańskiego, lecz również o negatywną ocenę jego filozofii mesjanizmu polskiego.

Krasiński nie był zwolennikiem nadawania dzieciom tylko tradycyjnych imion. Jego propozycje wymyślnych antroponimów uwidoczniają skłonność do „,natchnionego" etymologizowania nazw:

Myślałem prawie całą noc dzisiaj o ochrzczeniu Reyowej po polsku. Tyle imion przyszło mi do mózgu: D i a 1 i n a - co znaczy, że jest własnością Dialy; L u b i e n i c a - co znaczy, że 1 u b i ę- $\mathrm{N}$ i z z a;

M i 1 n i c a - od miłości;

D e $1 \mathrm{f}$ i n a - od Twego imienia;

I r y d i a - i to nieszpetne nazwisko - a wszystkie łatwe Włochom do wymówienia; 
R e s u r e c t i s - po łacinie.

Jakże Twoja biedna maleńka się nazywała? Od jej nazwiska można by nazwać. O pamiętam, pamiętam tę głowę idealną, podsuwającą się pod dłoń Twoją jak sen, który by śniły były palce ręki Twojej! Pamiętam, pamiętam, alboż ja cokolwiek zapomnieć mogę? I suknię nosiłaś granatową z camalią do pół wzrostu, i guziczki srebrne białe, i ja tę camalię tak kochałem, wtedy to się ręce Twojej marzyło wciąż! A gipsowa główka później w trzy czy cztery miesiące z Paryża przybyła z Tobą i do Włoch ją przywieźliśmy, chciałem ją umarmurzyć w Rzymie, aleś nie dała - i szkoda!

I d e a - można by nazwać;

S p i r i t o - można by.

Jeszcze pomyślę i w miarę, jak przyjdą na myśl imiona, przesyłać Ci je będę (L-D: 147-148).

\section{Uwagi językoznawcze w listach do Cieszkowskiego}

Kilka tego typu spostrzeżeń znajduje się w listach do wymienionego w podtytule przyjaciela. Najważniejsza jest ocena Juliusza Słowackiego jako mistrza polskiego języka poetyckiego: „Słowacki biedny z suchot umarł, a z wielką siłą ducha i pokojem. [...]. Mistrza takiego rymów język polski już nie dostanie. - Znikł człowiek, lecz póki mowy polskiej, póty i mienia jego" (L-C II: 158).

$\mathrm{Z}$ innego cytatu wynika, że Krasiński jest miłośnikiem staropolszczyzny, a to dowodzi, że dostrzega archaizmy językowe. List jest zagadkowy; najpierw dziękuje Cieszkowskiemu: „Dzięki ci za twój list z 1-go kwietnia i za wyłajanie mnie o s u p e r 1 a t y w (L-C II: 342). Chodzi najprawdopodobniej o nadmierne używanie form stopnia najwyższego przymiotników i przysłówków ${ }^{2}$. Następnie jest mowa o orędziu Piusa IX, którego pontyfikat przypadał na lata 1846-1878. Oto cytat: „Rzadko co mię w życiu tak uderzyło jak to orędzie. Jeśliś nie czytał, to cię zaklinam, to c i ę p o p r z y s i ę g a m (stara polszczyzna) przeczytaj! (L-C II: 343). Widocznie polski tłumacz tego orędzia posługiwał się częściowo dawnymi środkami językowymi.

Ostatnie dwie uwagi dotyczą problematyki stylu - jedna stylu polskiej publikacji i dwie stylu tekstów francuskich.

Za R o z b i ó r k w e st y i wło ś c i a ń s k i e j dziękuję ci wdzięcznie - od deski do deski te 718 kart przeczytałem, a szło gładko jak parowozem. Pyszne tam są kartki - niebotyczne, choć pisane stylem wieśniaczym i powtarzającym się. Taka miłość ducha, taka zacność przekonań, taka istotność smętku, że o formie się zapomina, niedba o nią; przeczytaj, szczególnie 2 ostatniej księgi, o R ó w n o ś c i b e z w z g 1 ę d n e j uwagi udały mu się ogromnie (L-C II: 286).

\section{Uwaga o publikacji Donoso Corteza:}

Dostań także: Esseai sur le Catholicisme Libéralisme et Socialisme par Donoso Cortez, dopiero co wyszłe. Pełno sofistyczności, ale też pełno genialnych błyskawic i gromów. To specy-

${ }^{2}$ Nawet w listach do Delfiny Potockiej jest ponad 20 osobliwych form stopnia wyższego i najwyższego przymiotników i przysłówków, np. przymiotniki: gorzkniejszy, niesprzeczniejszy, płomieniejszy, żałobniejszy, najanielszy, najumarlejszy; przysłówki: dowolniej, nieomylniej, najprzedziwniej. 
ficzna osobistość. Duch jak u Mestra, styl daleko dzierższy, puginałowy, namiętny. Hiszpan gębą całą (L-C II: 286).

Pisarz przez jednego z przyjaciół sprowadził (L-C II: 386) obszerną francuskojęzyczną broszurę Ludwika Mierosławskiego De la nationalité polonaise dans l'équilibre européen par le Général..., Paris 1856 (ss. XV + 531). Mierosławski (1814-1878) był bardzo znanym w XIX wieku polskim działaczem politycznym, dowódcą wojskowym (m.in. wodzem powstania 1848 roku w Wielkopolsce oraz dyktatorem na początku powstania styczniowego w 1863 roku), publicystą, historykiem wojskowości, a także powieściopisarzem i poetą. Jako syn Polaka i Francuzki był dwujęzyczny; pisał zarówno po polsku, jak i po francusku. Jego polskie teksty publicystyczne z historii wojskowości oraz utwory literackie cechuje nadużywanie osobliwych wyrazów oraz przedziwny styl (Jaskuła, Judek i in. 1982³). Oto kilkanaście osobliwości leksykalnych wspomnianego autora: niedoczyn (65 razy), bezbójny (54 r.), zwiednik (54 r.), bezslużbowiec (24 r.), czasotrwonny (16 r.), szujokracja (9 r.), poświęceniec (7 r.), daremnota (6 r.), porażeniec (5 r.), uniewładnić (5 r.), gadalnia (3 r.), plotkarnia ( 2 r.). Prawdopodobnie Mierosławski pisał w podobny sposób po francusku. Krasiński ocenia bardzo krytycznie styl wymienionej powyżej francuskojęzycznej publikacji Mierosławskiego (L-C II: 388-390).

Obiecałem ci zdać sprawę z wrażenia, jakie wywrze na mnie dzieło Mierosławskiego - oto je masz. Styl potworny, podobny do owych Bożyszcz indyjskich, co miasto dwóch nóg i rąk człowieczych mają ich sześćdziesiąt - podobny do tej Izydy Egipskiej, której na znak płodności i siły trzydzieści wymion zamiast piersi dwojga dali dziecinni jeszcze rzeźbiarze. [...] (L-C II: 388-390).

Krasiński pojmuje styl szeroko - podobnie jak rozumiano styl przed nim i przynajmniej do końca XIX stulecia. Przede wszystkim zwraca uwagę na ekspresywne środki językowe Donoso Corteza (stąd określenie: ,styl daleko dziarższy, puginałowy, namiętny"); chyba też ma na myśli ekspresję językową, gdy zwraca uwagę na demagogię Mierosławskiego widoczną w jego języku. Jako środek stylistyczny Corteza wyróżnia jego sofistyczność, tj. odzwierciedlający się w języku pokrętny sposób argumentowania (obfitujący w sofistyczne wykręty, niedomówienia itd.). Styl Rozbioru kwestyi włościańskiej Józefa Gołuchowskiego ${ }^{4}$ określa jako „wieśniaczy i powtarzający się". Powtórzenia treści świadczą niewątpliwie o monotonności wywodów i tym samym o nieporadności stylistycznej. Nie wiadomo, co znaczy wyrażenie styl wieśniaczy. Język wieśniaków to język chłopski - prosty pod względem leksykalnym i składniowym. Zapewne Krasińskiemu chodziło o takie braki stylistyczne broszury. Oprócz tego do stylu zalicza również interpretacje i poglądy autorskie dotyczące różnych wydarzeń (także historycznych), np. poglądy Mierosławskiego na temat stosun-

\footnotetext{
${ }^{3}$ Podstawa publikacji to 12 tomów drukowanych tekstów Mirosławskiego, m.in. Powstanie narodu polskiego w latach 1830 i 1831, t. I-VIII, Paryż 1845-1876, t. VIII, Poznań 1887. W tekstach tych znajdują się 1262 jednostki leksykalne, których nie odnotowały wcześniej wydane słowniki. Mirosławski należy do grona najbardziej „płodnych twórców” polskiego słownictwa (obok np. Jacka Przybylskiego, Joachima Lelewela, Zygmunta Krasińskiego) - Lewaszkiewicz 1975, 1980, 2021 - w druku).
}

${ }^{4}$ J. Gołuchowski, Rozbiór kwestyi włościańskiej w Polsce i w Rossyi w r. 1850, Poznań 1851. 
ków politycznych polsko-francuskich w epoce Napoleona i polsko-angielskich. Skoro nie akceptuje tych poglądów, to odpowiednie wypowiedzi traktuje jako stylistycznie nie do zaakceptowania.

Teoretyczna świadomość stylistyczna Krasińskiego nie odbiega od pojmowania stylu w XIX w. Naukowe podstawy stylistyki (strukturalnej) stworzył właściwie dopiero Charles Bally (1865-1947) w książce Précis de stylistique (1905) i w następnych publikacjach, a później teorię stylu znacznie pogłębiła praska szkoła strukturalistyczna.

\section{Podsumowanie i wnioski}

Krasiński najwięcej uwagi poświęcił „filozoficznej” istocie języka i pochodzeniu języków. Jego rozważania na te tematy, oparte na spekulatywnej i mistycznej filozofii, nie mają naukowego znaczenia, odzwierciedlają one silne związki pisarza z przemyśleniami religijnymi. Nieoryginalne, ale słuszne są natomiast refleksje o roli języka ojczystego w podtrzymywaniu tożsamości narodowej. Pisarz interesował się problematyką ortograficzną oraz poprawnością gramatyczną w używaniu polszczyzny. Sporo uwagi poświęcił ocenie stylu tekstów polskojęzycznych i francuskojęzycznych. Poglądy te nie były nowatorskie, ale na tle dziewiętnastowiecznej teorii stylistyki nie można im odmówić wartości. Mało istotne są inne wzmianki - o bogactwie języka Słowackiego oraz propozycje imion dla dzieci wraz z ,natchnionymi” pomysłami etymologicznymi.

\section{Bibliografia}

Edycje listów

L-D: Z. Krasiński, Sto listów do Delfiny. Wyboru dokonał i wstępem opatrzył J. Kot, Warszawa 1966.

L-C I, II: Listy Zygmunta Krasińskiego do Augusta Cieszkowskiego z autografów wydat Józef Kallenbach, wstępem opatrzył Adam Żółtowski, t. I-II, Kraków 1912.

\section{Literatura naukowa}

Janion M., 1962, Zygmunt Krasiński. Debiut i dojrzałość, Warszawa.

Jaskuła B., Judek C., Lewaszkiewicz K., Lewaszkiewicz T., 1982, Osobliwości leksykalne języka Ludwika Mierostawskiego (1814-1875), „Studia Polonistycznie UAM”, s. 37-60.

Kurkowska H., 1950, Językoznawstwo natchnione, „Poradnik Językowy”, z. 2, s. 8-11.

Lewaszkiewicz T., 2017, Pisarze, publicyści i thmacze jako językoznawcy, kodyfikatorzy oraz reformatorzy języków słowiańskich, w: Literature and Social Change: A Voyage Through the History of Slavic Studies, ed. by L'. Matejko, Bratislava, s. 83-108.

Lewaszkiewicz T., 2021, Słowotwórcze osobliwości leksykalne Zygmunta Krasińskiego w listach do Delfiny Potockiej (w druku). 
Lewaszkiewicz T., Walczak B., Zgółkowa H., 1984, Cyprian Kamil Norwid jako lingwista i filolog, „Studia Polonistyczne” XI/XII, s. 165-204.

Papierkowski S.K., 1972, Stefan Żeromski jako znawca i miłośnik języka polskiego, w: S.K., Papierkowski, Z badań nad językiem i literatura, Lublin, s. 158-217.

Pihan A., 1990, Poglady J. I. Kraszewskiego na język i jego praktyka pisarska, w: Język. Teoria. Dydaktyka, red. M. Preizner, Kielce, s. 103-113.

Sokólska U., 2015, Język jako przedmiot refleksji w pismach Melchiora Wańkowicza, w: Język pisarzy: problemy metajęzyka i metatekstu, t. 6, red. T. Korpysz, A. Kozłowska, Warszawa, s. 183-197.

Walczak B., 1998, Adama Mickiewicza Pomysty etymologiczne, w: Studia nad językiem Adama Mickiewicza, red. M. Białoskórska, L. Mariak, Szczecin, s. 113-126.

Walczak B., 1999, Adam Mickiewicz o językach stowiańskich, „Poznańskie Spotkania Językoznawcze”, t. V, cz. 2, red. Z. Krążyńska i Z. Zagórski, Poznań, s. 105-115.

\title{
TADEUSZ LEWASZKIEWICZ
}

\section{The linguistic interests of Zygmunt Kraiński}

\begin{abstract}
Zygmunt Krasiński devoted much if his attention to the "philosophical" essence of the language and the origins of various tongues. His conjectures, based on speculative and mystic philosophy, are of no scientific importance; rather, they reflect the author's strong attachment to religion. While not original, his views on the role of a mother tongue in preserving national identity are correct. The writer was interested in spelling and correct grammatical usage of the Polish language. He also focused on assessing the style of texts written in Polish and French. His views were hardly innovative, offering some value in comparison with the $19^{\text {th }}$ century theory of style. Other language-related mentions: the sophistication of Juliusz Słowacki's language and proposals of baby names based on "inspired" etymological ideas, are inconsequential.
\end{abstract}

Keywords: Zygmunt Krasiński, linguistic interests of writers. 